\title{
INCREASING OF COMPETITIVENESS IN EAST EUROPEAN COUNTRIES BY COMPUTER AIDED Process PlanNing
}

\author{
MONKA, P. \& MONKOVA, K.
}

Abstract: The process planning activities are significant means for flexibility, time to market and competitive advantage of enterprise. The process planning systems are therefore important tools for increasing of efficiency and profit.

In many East European countries is needful for application of modern processes at time of Product \& Manufacturing Design. When designing the new product the aim is to secure or increase its technical value not only by systematization of the production process but also by increasing the level of the supporting tools for the rational processing of the production documentation and data needed for planning.

Key words: Computer Aid, Process Plan, Process Planning, Information System
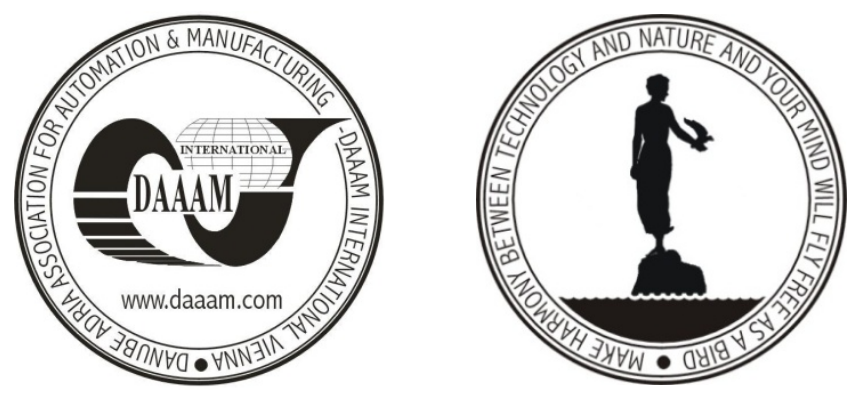

Authors' data: Dr. Doc. Eng. PhD. / prelector Monka, P[eter]; Dr. Doc. Eng. PhD. Monkova, K[atarina], Technical University in Kosice, Facuty of Manufacturing Technologies with seat in Presov, Department of Production Technologies, Pod Kalvariou 61, 080 01, Presov, SK, direct@apeiron.eu, monkova.Katarina@apeiron.eu

This Publication has to be referred as: Monka, P[eter] \& Monkova, K[atarina] (2008). Increasing of Competitiveness in East European Countries by Computer Aided Process Planning, Chapter 44 in DAAAM International Scientific Book 2008, pp. 525-534, B. Katalinic (Ed.), Published by DAAAM International, ISBN 978-3901509-66-7, ISSN 1726-9687, Vienna, Austria

DOI: $10.2507 /$ daaam.scibook.2008.44 